\title{
Product Features and Customers Satisfaction of Patanjali Product: Evidence From Kathmandu, Nepal
}

Ballav Niroula ${ }^{1}$,

${ }^{1}$ Faculty of Management - Patan Pultiple Campus - Tribhuvan University - Nepal,

Achyut Gyawali

${ }^{2}$ Department of Management - Tribhuvan University - Kathmandu - Nepal

Correspondence Email: ballavsir@gmail.com
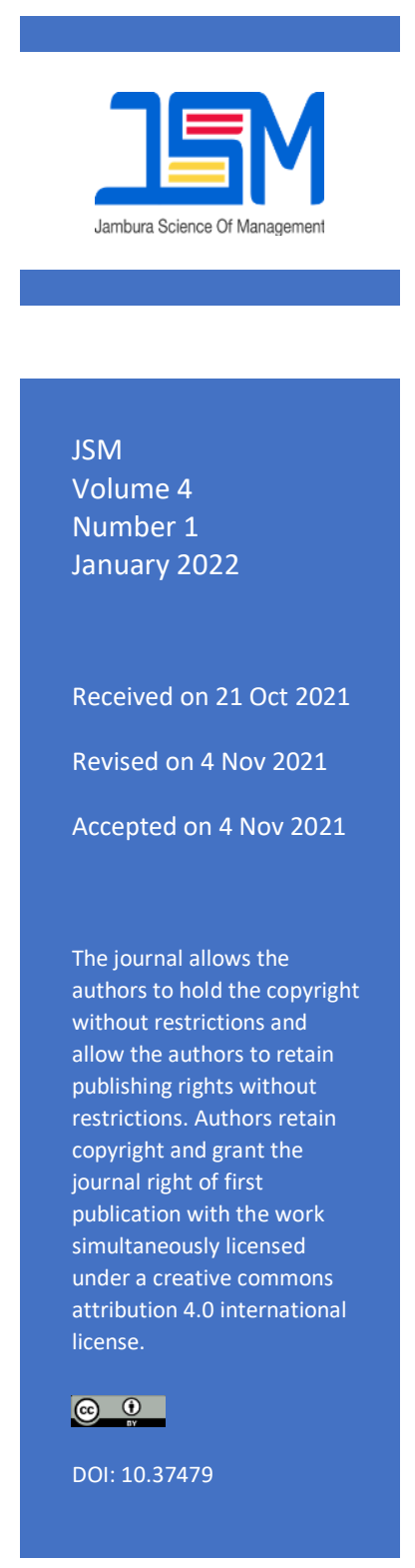

\begin{abstract}
Purpose: The objectives of this study are to identify the features of Patanjali products and it focuses to identify the satisfaction level and purchasing decision of consumer by the features of Patanjali products.
\end{abstract}

Design/Methodology/Approarch: In this research, convenient sampling technique were used to get the sample, correlation and regression were used in order to get the result. Descriptive statistics is used to explain the respondents' perception towards the features of Patanjali product. In this study, the data was collected through questionnaire from 300 respondents. This research used SPSS - 23 for analysis. This study has been done on four attributes or determinants of Patanjali product, they are price, quality, availability and healthy (organic) of product.

Findings: The result of this study indicates that there is positive relationship between the features of Patanjali product and satisfaction. It can be said that the independents variables have effect on consumer satisfaction of Patanjali products. The producer and marketing managers are recommended to focus on the product features in order to obtain loyal satisfied customers.

Keywords: Customer satisfaction; Loyalty; Patanjali Product features; Purchase decision

\section{INTRODUCTION}

Customer's decision making is one of the most important topics in a rapid changing business environment. Product valuation is the core determinant of the consumer choice. Product features are important to both consumers and marketers. The consumer uses features as the basis for evaluating a product since features of product provide benefits the customer seeks when purchasing a product and comparing between competitive brands. Consumers also evaluates features more positively or negatively, which is perceived as being important in the decision-making process. The marketer uses features of product to differentiate his brand from competitive brands and as the basis for the development of new products.

Research Carpenter et al (1994) has showed that although the general view is that product differentiation is done through features that are 
meaningful, relevant and valuable, many brands successfully differentiate themselves from competitors by focusing on attributes. Aaker et al (1992) explained that an important attribute is one that is considered an important benefit towards the satisfaction of consumer needs.

Consumer satisfaction has been very well-known in marketing where as it is as the basic focus in achieving business objective, vision and also mission (Anderson et, al, 1994). Consumer satisfaction is customer evaluation or felt towards a product after usage that does the product itself differs from some of the features or factors through the expectation and also the presentation of the product itself (Yi, 1990; Day, 1984; Kotler, 1991; Parasuraman et al., 1985, 1988; and Tse and Wilton, 1988). Customer satisfaction a fresh thought that is used to be the representative to the wholly after purchasing effects on the products after a duration (Anderson et al., 1994; Fornell, 1992; Johnson and Fornell, 1991). Satisfaction is an internal view which offshoot from customer's own experience of a consumption or service experience. The connection between customer satisfaction and company success has traditionally tied to faith and numerous satisfaction studies have supported this position (Hill and Alexander, 2000). Customer satisfaction has always been considered a vital business goal because of its crucial role in the formation of customers' desire for future purchase or tendency to buy more (Mittal and Kamakura, 2001).

Patanjali Ayurveda Kendra private limited is an Indian FMCG (Fastmoving consumer goods) company. Which was officially formed on 13th January 2006 by Param Pujya Yog Rishi Swami Ramdev and Ayurveda Shiromani Balkrishna Achraya. Manufacturing units and headquarters are located in the industrial area of Haridwar while the registered office is located at Delhi, India. The company mainly produced herbal related various products (manufactures mineral and herbal products). It also has manufacturing unit in Nepal under the trademark Nepal Gramudhyog and imports majority of herbs in India from Himalayas of Nepal. It is the fastest growing FMCG (Fastmoving consulmer goods) Company in India. This study aims to identify the features of Patanjali products and it also focuses to identify the satisfaction level and purchasing decision of consumer by the features of Patanjali products.

Gosher (2017) carried out the study to know why customers prefer Patanjali products. Patanjali Ayurveda home-grown firm in businesses such as food, consumer packaged goods and healthcare. Both primary and secondary data were collected for research survey and the primary instrument for data collection used in this study was a questionnaire. Primary data was collected from 60 respondents from the city of Mumbai suburban. The sampling method used in the study was random sampling. The study has revealed that the people between the age group of 15-45 are the major consumers of Patanjali products. It was observed that between age group of 15-25 years are preferring cosmetics. Price has become a significant factor along with Ayurveda 
and herbal. However, Patanjali is entering into much business it is suggested that it focus on more cosmetic, health and food related products.

Anderson (1973) predicted the effects on product evaluation and customer satisfaction of disparity between expectations and actual product performance. Four psychological theories may be considered for the study: cognitive dissonance, contrast, generalized negativity, and assimilation contrast. A 2X6 factorial design was used to test the study. Characteristics like general appearance, quality, durability and general feel are examined. Results reveal that too great a gap between high consumer expectations and actual performance may cause a less favorable evaluation of a product than a somewhat lower level of disparity. Bettman (1974), examined information processing carried out by consumers in the course of decision making about whether or not a feature of a product is satisfactory to them. For that the researcher develops a model of feature satisfaction decisions using Fishbone- type measure. The product category used for testing the model was tooth paste. Five features and three variables were tested: whitening teeth, preventing cavities and decay, economical to use, freshening the breath, and pleasant tasting and beliefs, familiarity and evaluation. Data were collected from 121 graduates and under graduate students. Multivariate profit analysis and multiple regression models were used to test the model. The results showed that there was a relationshi Westbrook (2001) developed conceptualization of retail satisfaction and studied the sources of consumer satisfaction in retail outlets. A judgmental area sampling procedure was employed to select locales within the city. Personal home interviews were conducted with a sample of 206 adult females. Data were gathered through structured questionnaires administered by qualified interviewers. Items to identify consumers evaluations of their in store experiences are the helpfulness, friendliness, number of sales people, politeness of sales people, attractiveness of store, layout of store, roominess, case of finding, cleanliness, assortment, quality, value for money, fair, willingness to exchange, credit, location, price level, sales and advertising. Factor analysis were employed. The findings of the study provided considerable support for the conceptualization of retail satisfaction. Consumers were found readily able to express sentiments of satisfaction with the retail outlets.p between the features and satisfaction decisions.

Kristensen, et al. (1999) examined empirically to what extended expectations have a measurable influence in the formation of customer satisfaction. Two Danish studies form MSc students have been carried out. First, an experiment where the relationships between expectation, perceived quality and customer satisfaction were studied, second, a customer satisfaction survey using the questionnaire. They developed five models of customer satisfaction formation by using the literature of Oliver (1977, 1980, 1981), Anderson (1973), Churchill and Suprenant (1982), Bearden and Teel (1983), Woodruff et. Al (1991), Oliver and Desarbo (1988), Spreng and Olshavsky (1993). By 
using product category characteristics as price, complexity, and sing value and product category as perfume, cigarettes, washing powder, battery, bed, contact lenses, personal computer, stereo equipment and variables as customer expectations, perceived quality and customer satisfaction.

Structural equation model was used to estimate and test the process of customer satisfaction. The result showed that perceived quality drives customer satisfaction and customer expectations have no substantive effect on satisfaction.

Thanet (2017) examined consumer attitude towards Patanjali brand. The study has used descriptive statistic, correlation and regression to identify the effect of attitude in brand. In the study, cognition, affection and behavior are major determinant factor of attitude and it also find the other reasons for preferring Patanjali brand are price, quality, brand image, availability. The result shows there is significant high association between the overall attitude of respondent and dimensions of attitude.

Karki and Regmi (2016) analyzed consumer satisfaction towards Nepalese coffee. This study shows that price and lack of awareness is the major reasons for less consumption of Nepalese coffee. It was therefore, recommended that the service provider must improve its awareness, availability pricing strategy.

Koirala and Shrestha (2012) studied service quality and customer satisfaction with respect to service quality dimensions. The study has used descriptive statistics, correlation and regression analysis to measure relationship among service quality dimension and customer satisfaction. The study found that customer satisfaction is highly affected by service quality.

\section{Conceptual Framework}

The aim of this section is to summarize the idea got from past literature. Conceptual framework is the foundation on which the study is based. It describes the relationship between dependent variables and independent variables. The product feature is important factor that effect the consumers' satisfaction and this will evaluate with the help of four product feature dimensions. On the independent variable we have price of product, quality of product, easily available of product and healthy product medicine purpose). The following framework can derive from review of existing literature and research papers. 


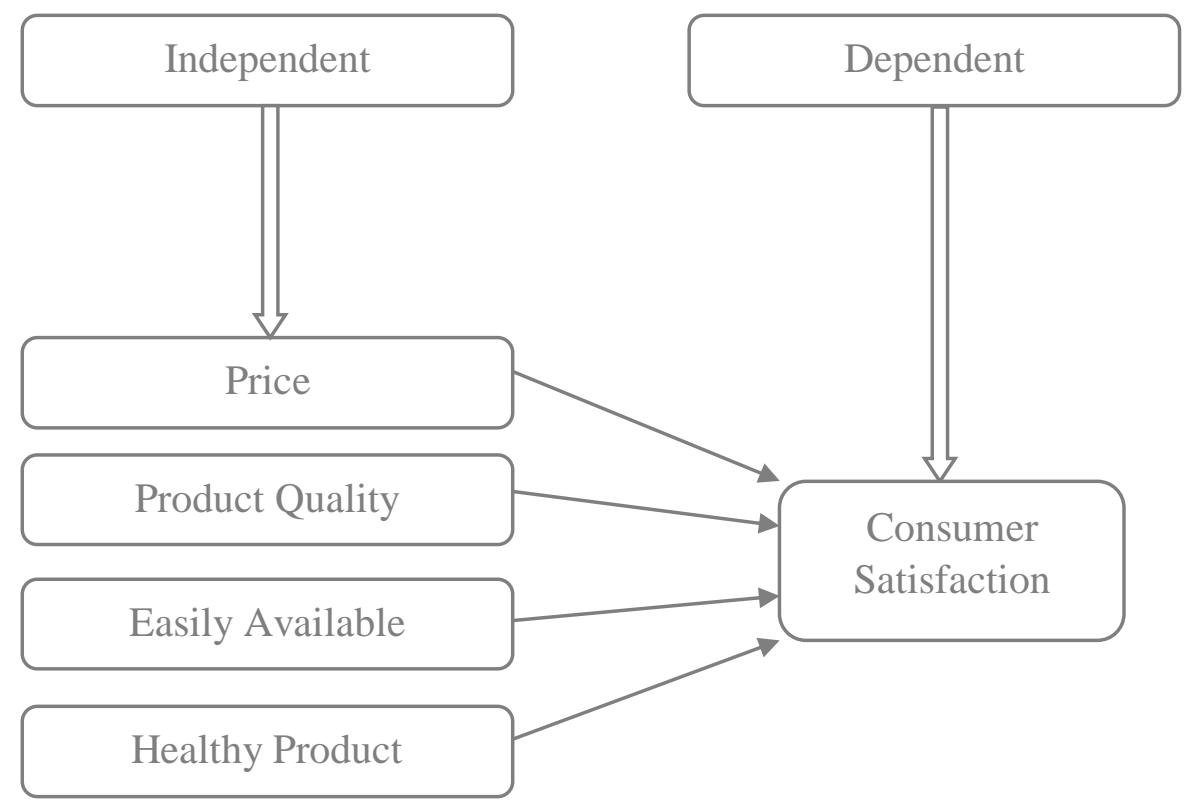

Figure 1. Conceptual Framework.

The conceptual framework is based on the Antecedent and Consequence service quality model (Dabholkar et. al; 2000, Brady et. al; 2002). A comprehensive model of service quality, this model examines some conceptual issues in service quality as: the relevant factors related to service quality better conceived as components and relationship of customer satisfaction with behavioral intentions. Product/service quality is main antecedent of customer satisfaction (Anderson \& Sullivan 1993, Brady et. al; 2002).

\section{Research Hypotheses}

Based on the above conceptual framework, following alternative hypotheses to be taste

(H1) There is significant impact of price on customer satisfaction.

(H2) There is significant impact of quality of product on customer satisfaction.

(H3) There is significant impact of availability of product on customer satisfaction.

(H4) There is significant impact of healthy product on customer satisfaction

\section{METHODS}

A descriptive research design has been used for the research since this study is based on the assessment of people opinion and respondent's satisfaction. The population of this study will the whole the customer who has been using the Patanjali product in Kathmandu city of Nepal. The sample size is referred to the sub-set of the population. For this study the sample size is 300, [sample size is calculation based on Yamane formula method, i.e. sample size $=\mathrm{N} /(1+\mathrm{Ne} 2)]$ consumer or user of Patanjali product in Kathmandu city. Respondents were selected on the basis of convenience sampling method from 
consumers visiting stores and retailers. For the survey 30 questions were prepared and all the response were collected by filling all questionnaire by respondents individually. The questions were also prepared in the Likert scale design. It is measured in Likert scale where 1- strongly disagree, 2- disagree, 3- neutral, 4- agree and 5strongly agree. The data collected through questionnaire were analyzed through the SPSS - 23 and Microsoft excel software. Descriptive and inferential statistics were used to make proper analysis.

Cronbach's Alpha is most commonly used approach to test reliability of items of questions used in questionnaire. Nunnaly (1978), the value of Cronbach's alpha should be 0.700 or above. But some of the study also considered 0.600 as acceptable value (Gerrard, Cunningham \& Devlin 2006). The value of Cronbach's Alpha of selected variables such as price $(0.650)$, quality $(0.684)$, availability of product (0.658), healthy product (0.824) and consumer satisfaction (0.928) were separately tested to make certain designed all question are reliable. All the values of Cronbach's Alpha are greater than 0.600 , so, according to the thumb rule all the variables are acceptable.

\section{RESULTS AND DISCUSSION}

The aim of this section is to present the characteristics of the research variables and the findings based on the data obtained from the survey. Major objective of the study is to measure the association between the dimensions of the features i.e. price, quality, availability of and healthy product and its satisfactions toward the Patanjali brand.

\section{Respondents Profile}

Table 1. Profile of the Respondents

\begin{tabular}{|c|c|c|}
\hline Gender & Frequency & Percent \\
\hline Male & 164 & $54.7 \%$ \\
\hline Female & 136 & $45.3 \%$ \\
\hline Total & 300 & 100 \\
\hline \multicolumn{3}{|l|}{ Uses of Patanjali products } \\
\hline Food item & 116 & 38.67 \\
\hline Beauty product & 80 & 26.67 \\
\hline Medicine & 52 & 17.33 \\
\hline Hair care & 34 & 11.33 \\
\hline Dental care & 16 & 3.33 \\
\hline Total & 300 & 100 \\
\hline \multicolumn{3}{|l|}{ Duration of using Patanjali products } \\
\hline less than $1 \mathrm{yr}$ & 132 & 44 \\
\hline $1-2 \mathrm{yr}$ & 106 & 35.33 \\
\hline $3-4 y r s$ & 16 & 5.33 \\
\hline more than 4 yrs & 46 & 15.34 \\
\hline Total & 300 & 100 \\
\hline \multicolumn{3}{|l|}{$\begin{array}{l}\text { Reason for preferring the Patanjali } \\
\text { products }\end{array}$} \\
\hline Price & 144 & 48 \\
\hline Quality & 168 & 56 \\
\hline Easily available & 24 & 8 \\
\hline Brand image & 50 & 16.67 \\
\hline Packaging & 16 & 5.33 \\
\hline
\end{tabular}




\begin{tabular}{lcc}
\hline Total & 300 & 100 \\
\hline
\end{tabular}

Source: Field Survey (2021)

\section{Descriptive Analysis}

Descriptive statistics is used to analyze the data collected from the respondents during the research process. Mean and Standard Deviation analysis are used in this study to analyze data. The higher mean value means more respondents agreed to those variables. Descriptive analysis is a summary statistic that quantitatively describe or summarize feature of a collection of information. Mean is measured as measure of central tendency and standard deviation is measured as measure of variability of different variables of the study like price, quality of product, availability of product, healthy product and consumer satisfaction.

\section{Price of Product}

This section explores the association of price of product towards consumer satisfaction through descriptive analysis. For the study of consumer satisfaction regarding the price of product, 5 different questions statement were studied. It is measured in Likert scale where 1- strongly disagree, 2- disagree, 3- neutral, 4- agree and 5- strongly agree. The view of respondent is observed by figuring its mean and standard deviation.

Table 2. Effects of Price on Satisfaction.

\begin{tabular}{|c|c|c|c|c|c|}
\hline Code & Opinion statement & $\mathbf{N}$ & $\begin{array}{c}\text { Test } \\
\text { Scale }\end{array}$ & Mean & S.D. \\
\hline $\mathrm{P} 1$ & $\begin{array}{l}\text { Price of Patanjali products is } \\
\text { reasonable. }\end{array}$ & 300 & 3 & 3.940 & .687 \\
\hline $\mathrm{P} 2$ & $\begin{array}{l}\text { The price is the reason that } i \text { switch } \\
\text { to } \\
\text { Patanjali products. }\end{array}$ & 300 & 3 & 3.513 & .872 \\
\hline P3 & $\begin{array}{l}\text { Patanjali products price is lower } \\
\text { than other brand products. }\end{array}$ & 300 & 3 & 3.486 & .857 \\
\hline $\mathrm{P} 4$ & $\begin{array}{l}\text { Price of Patanjali products } \\
\text { compromise its quality. }\end{array}$ & 300 & 3 & 3.266 & 1.127 \\
\hline P5 & $\begin{array}{l}\text { Buying the Patanjali products are } \\
\text { worthful. }\end{array}$ & 300 & 3 & 3.733 & .945 \\
\hline & Average Price & 300 & 3 & 3.588 & 0.898 \\
\hline
\end{tabular}

Source: Field Survey (2021)

Table 2 presents descriptive statistics on how the respondents regard various statements of price of the product. It shows the higher mean on "Price of Patanjali products are reasonable." i.e. 3.94 which shows that the consumers are agreed that the Patanjali products has a reasonable price to all the (income) level of people. The lower mean i.e. 3.2667 on "Price of Patanjali products compromise its quality." means consumers moderately agree that the price of product can compromise the quality of product. Similarly, the higher standard deviation is 1.12725 , it indicates that there is more variation on mean whereas the lower standard deviation i.e. 0.68767 indicates that the less variation on mean. 


\section{Quality of Product}

This section explores the association of price of product towards consumer satisfaction through descriptive analysis. For the study of consumer satisfaction regarding the price of product, 5 different questions statement were studied. It is measured in Likert scale where 1- strongly disagree, 2- disagree, 3- neutral, 4- agree and 5- strongly agree. The view of respondent is observed by figuring its mean and standard deviation.

Table 3. Effects of Quality on Customer Satisfaction

\begin{tabular}{|c|c|c|c|c|c|}
\hline Code & Opinion statement & $\mathbf{N}$ & $\begin{array}{l}\text { Test } \\
\text { Scale }\end{array}$ & Mean & S.D. \\
\hline Q1 & $\begin{array}{l}\text { Patanjali product has better quality than other } \\
\text { product. }\end{array}$ & 300 & 3 & 3.940 & .687 \\
\hline Q2 & $\begin{array}{l}\text { Quality of product is important than another feature } \\
\text { of product. }\end{array}$ & 300 & 3 & 3.726 & .866 \\
\hline \multirow{3}{*}{ Q3 } & & 300 & & & \\
\hline & I feel secure while using the patanjali product. & & 3 & 3.693 & .694 \\
\hline & Average Price & 300 & 3 & 3.786 & 0.749 \\
\hline
\end{tabular}

Table 3 presents descriptive statistics on how the respondents regarded various statements of quality of Patanjali product. It shows the higher mean on "Patanjali product has better quality than other product." i.e. 3.94 which shows that customers highly agreed to the statement. The lower mean i.e. 3.693 on statement "I feel secure while using the patanjali product" Means customers are moderately agreed on it. Similarly, the higher standard deviation is 0.787 , on "quality of product is important than other features of product." indicates that there is more variation on mean whereas the lower standard deviation i.e. 0.465 , on the statement "Patanjali products are substandard." indicates that the less variation on mean.

\section{Availability of Product}

This section explores the how availability of Patanjali product affects the satisfaction of consumers through descriptive analysis. For the study of these 4 different statements were studied. It is measured in Likert scale where 1- strongly disagree, 2- disagree, 3- neutral, 4agree and 5- strongly agree. The view of respondent is observed by figuring its mean and standard deviation.

Table 4. Effects of Availibility of Product on Satisfaction

\begin{tabular}{llcccc}
\hline Code & \multicolumn{1}{c}{ Opinion statement } & N & $\begin{array}{c}\text { Test } \\
\text { Scale }\end{array}$ & Mean & S.D. \\
\hline EA1 & $\begin{array}{l}\text { Patanjali store can be found in every } \\
\text { city location. }\end{array}$ & 300 & 3 & 3.726 & 0.866 \\
EA2 & $\begin{array}{l}\text { Patanjali products are available in } \\
\text { super market and pharmacy. }\end{array}$ & 300 & 3 & 3.633 & 0.958 \\
EA3 & $\begin{array}{l}\text { Patanjali store is near to my location. } \\
\text { Eann }\end{array}$ & 300 & 3 & 3.773 & 0.820
\end{tabular}




\begin{tabular}{lrrrr} 
EA4 $\begin{array}{l}\text { Patanjali brand has verities of product } \\
\text { categories. }\end{array}$ & 300 & 3 & 3.987 & 0.866 \\
\hline Average & 300 & 3 & 3.780 & 0.877 \\
\hline
\end{tabular}

Source: Field Survey (2021)

Table 4 presents descriptive statistics on how the respondents regarded various statements of availability of Patanjali product. It shows the higher mean on "Patanjali brand has verities of product categories." i.e. 3.986 which shows that customers highly agreed to the statement. The lower mean i.e. 3.633 on statement "Patanjali products are available in super market and pharmacy." Means customers are moderately agreed to the statement.

Similarly, the higher standard deviation is 0.958 , on "Patanjali products are available in super market and pharmacy." indicates that there is more variation on mean whereas the lower standard deviation i.e. 0.820 , on the statement "Patanjali store is near to my location." indicates that the less variation on mean.

\section{Healthy Product}

This section explores the association of healthy product towards consumer satisfaction through descriptive analysis. For the study of consumer satisfaction regarding the healthy product, 5 different questions statement were studied. It is measured in Likert scale where 1- strongly disagree, 2- disagree, 3- neutral, 4- agree and 5- strongly agree. The view of respondent is observed by figuring its mean and standard deviation.

Table 5. Effects of Healthy Product on Satisfaction

\begin{tabular}{|c|c|c|c|c|c|}
\hline Code & Opinion statement & $\mathbf{N}$ & $\begin{array}{c}\text { Test } \\
\text { Scale } \\
\end{array}$ & Mean & S.D. \\
\hline HP1 & Patanjali products are safe to use. & 300 & 3 & 3.993 & 0.537 \\
\hline HP2 & Patanjali products are pure and herbal. & 300 & 3 & 3.853 & 0.754 \\
\hline HP3 & $\begin{array}{l}\text { Patanjali medicine are very much } \\
\text { useful. }\end{array}$ & 300 & 3 & 3.693 & 0.694 \\
\hline HP4 & $\begin{array}{l}\text { Patanjali product has no side effect as it } \\
\text { is herbal and natural product. }\end{array}$ & 300 & 3 & 3.686 & 0.828 \\
\hline HP5 & $\begin{array}{l}\text { It cures different pain, disease and } \\
\text { chronic disease. }\end{array}$ & 300 & 3 & 3.580 & 0.788 \\
\hline & Average Price & 300 & 3 & 3.761 & 0.720 \\
\hline
\end{tabular}

Table 5 presents descriptive statistics on how the respondents regarded various statement of healthy product (organic) of Patanjali. It shows the higher mean on "Patanjali products are safe to use." i.e. 3.993 which shows that the customers were agreed on the statement. The lower mean value is 3.58 on "it cures different pain, disease and chronic disease" mean the customers were moderately agreed to the statement. Similarly, the higher standard deviation is 0.828 on the statement "Patanjali product has no side effect as it is herbal and natural product" indicates that there is more variation on mean 
whereas the lower standard deviation is 0.537 on the statement "Patanjali products are safe to use" indicates the less variation on mean.

\section{Customer Satisfaction on Product}

This study also examined the satisfaction of customer of the Patanjali product different features. Respondents were provided 7 different statements to express their opinion. For the study of consumer satisfaction regarding the healthy product, 5 different questions statement were studied. It is measured in Likert scale where 1strongly disagree, 2- disagree, 3- neutral, 4- agree and 5- strongly agree. The view of respondent is observed by figuring its mean and standard deviation.

Table 6. Consumer Satisfaction on Features of Product

\begin{tabular}{|c|c|c|c|c|c|}
\hline Code & Opinion statement & $\mathbf{N}$ & $\begin{array}{l}\text { Test } \\
\text { Scale }\end{array}$ & Mean & S.D. \\
\hline CS1 & $\begin{array}{l}\text { Patanjali products meet } \\
\text { my needs. }\end{array}$ & 300 & 3 & 3.846 & 0.662 \\
\hline CS 2 & $\begin{array}{l}\text { Owing Patanjali products } \\
\text { has been good experience. }\end{array}$ & 300 & 3 & 3.833 & 0.689 \\
\hline CS 3 & $\begin{array}{l}\text { Patanjali product meet my } \\
\text { need and standout with my } \\
\text { expectation. }\end{array}$ & 300 & 3 & 3.606 & 0.749 \\
\hline CS 4 & $\begin{array}{l}\text { Patanjali products are } \\
\text { better than other products } \\
\text { I currently familiar with. }\end{array}$ & 300 & 3 & 3.653 & 0.874 \\
\hline CS 5 & $\begin{array}{l}\text { I am happy and satisfy } \\
\text { with Patanjali products. } \\
\text { My choice to buy the }\end{array}$ & $\begin{array}{l}300 \\
300\end{array}$ & 3 & 3.853 & 0.708 \\
\hline CS6 & $\begin{array}{l}\text { Patanjali product was a } \\
\text { wise one. }\end{array}$ & & 3 & 3.846 & 0.808 \\
\hline \multirow[t]{2}{*}{ CS7 } & $\begin{array}{l}\text { I recommend to my friend } \\
\text { to use the } \\
\text { Patanjali products. }\end{array}$ & 300 & 3 & 3.966 & 0.669 \\
\hline & $\begin{array}{ll}\text { Average } & \text { Customer } \\
\text { Satisfaction } & \end{array}$ & 300 & 3 & 3.8010 & 0.737 \\
\hline
\end{tabular}

Source: Field Survey (2021)

Table 6 presents descriptive statistics on how the respondents regarded various statement of customer satisfaction. It shows the higher mean on the statement "I recommend to my friend to use the Patanjali products" i.e. 3.966 which shows that customers are agreed to the statement. The lower mean of 3.067 on "Patanjali product meet my need and standout with my expectation" means customer are moderately agreed to the statement.

Similarly, the higher standard deviation of 0.874 on "Patanjali products are better than other products I currently familiar with" indicates that there is more variation on mean whereas the lower standard deviation is 0.662 on "Patanjali products meet my needs" indicates the less variation on mean. 


\section{Result of Hypotheses}

Table 7. Result of Hypotheses

\begin{tabular}{clc}
\hline Hypothesis & \multicolumn{1}{c}{ Statements } & $\begin{array}{c}\text { Accepted/ } \\
\text { Rejected }\end{array}$ \\
\hline H1 & $\begin{array}{l}\text { There is significant impact of price of product on } \\
\text { customer satisfaction. }\end{array}$ & Accepted \\
H2 & $\begin{array}{l}\text { There is significant impact of quality of product } \\
\text { on customer satisfaction. } \\
\text { There is significant impact of availability of } \\
\text { product on customer satisfaction. }\end{array}$ & Accepted \\
\hline H4 & $\begin{array}{l}\text { There is significant impact of healthy (organic) of } \\
\text { product on customer satisfaction. }\end{array}$ & Accepted \\
\hline
\end{tabular}

Source: Field Survey (2021)

\section{CONCLUSION}

The study mainly focused on analyzing the element of product attribute of Patanjali affecting the customer satisfaction. The study includes four elements of product attributes as price of product, quality of product, availability of product and healthy of product. The result are based on the response of 300 respondents and questionnaire. The descriptive analysis revealed that as comparing the respondent's profile, there are more female users of Patanjali products to male. And the number of consumers is increasing as compared to the previous years, as number of respondents for less than 1 year or 1-2 years are almost double to that of 3-4 years and more than 4 years of consuming Patanjali products. Television and radio are the major source of information for the respondents. And the used products of Patanjali is food item according to response of the respondents and then Patanjali beauty products followed by medicine products usages, hair care and dental care. The main reason for preferring the Patanjali products is quality and then price followed by brand image, medical usages, easily availability and packaging of the product. It is also found out that all alternative hypothesis were accepted that means price, quality, availability and healthy products have affected on customer satisfaction.

The finding from the study is useful for the Patanjali products suppliers that price, availability and healthiness are the major determinant of the Patanjali products. So, the marketing manager can develop plan according to it. Similarly, satisfied consumers of Patanjali products shows the behavior to recommend other to use the Patanjali products and long-term users of Patanjali also show positive response to prefer new products of Patanjali. The company willing to increase number of satisfied customers, if they focus on their product attributes, what determinant is most important to customer and what are the expectation of customer from the product. Customer may switch to competitors' product if they have negative perception or dissatisfaction without any second thought. Customer satisfaction is key and important element for the company to sustain and to get grow. Thus, company must aware about the factor or the product 
determinants and should have to make good strategic plan to get customer satisfaction.

\section{RECOMMENDATION}

This research study has some limitations which can be avenues for future research. The study has examined the limited variables there are other different variables like income level, target market place, brand image etc. for the future research. The research is conducted Kathmandu valley only. Further study may have conducted to other city/ parts of Nepal. This study has taken only 300 respondents, for future study can be done with more numbers of respondents. The study has done on Patanjali product, future research can be conducted to other brands like Unilever, Dabur and other brands as well.

\section{REFERENCES}

Aaker, D. A. (1992). The Value of Brand Equity. Journal of Business Strategy. 13(4).

Anderson, E. W., Formelo, C., Lehmann, D. R. (1994). Customer Satisfaction, Market Share, and Profitability: Findings from Sweden. Journal of Marketing, 58(3). 53-66.

Carpenter, G. S., Glazer, R., Nakamoto, K. (1994). Meaningfull Brands From Meaningless Differentiation. The Dependence on Irrelevant Attributes. Journal of Marketing Research. 31(3).

Engel, J. F., Blackwell, R. D., \& Miniard, P. W. (1995). Consumer behaviour. Fort Worth, TX: Dryden.

Fernqvist, F., \& Ekelund, L. (2014). Credence and the effect on consumer liking of food-A review. Food Quality and Preference, 32, 340-353.

Gosher, D.S. (2017). Customer preferences towards Patanjali product: A study on consumer with reference to Mumbai suburban district. IJARIIE, 3760-3765.

Hill, N., \& Alexander, J. (2000). Handbook of customer satisfaction and loyalty measurement (2nd ed.) England: Gower Publishing Ltd.

Home, W. (2000). An overview of customer satisfaction model. RP group proceeding, 100-112.

Horovitz, J. (2000). The seven secrets of service strategy. Financial Times-Prentice Hall, Harlow.

Jamkatel, B.P. (2018). An analysis of the customer satisfaction from service quality of Himalayan airline. International Journal of social science \& Management, 69- 71.

Janiszewski, C., \& Lichtenstein, D. R. (1999). A range theory account of price perception. Journal of Consumer Research, 25(March). 353-368. 
Kim, X., Lee, S. Y., Joo, Y., \& Yuan, K. J., (2014). How perceived quality works in new technology adoption process: A crossnational comparison among China, Korea and Japan. Journal of Global Information Technology Management, IV (54).

Kotler, P (2002). Marketing management, 21C Upper Saddle River, USA: Pearson Education Incorporation. Pearson Prentice Hall.

Kumar, M. R., \& Janagam, D. (2011). Export and Import Pattern of Medicinal Plants in India. Indian Journal of Science and Technology, IV (3), 245-248.

Lancaster, K. J. (1966). A new approach to consumer theory. Journal of Political Economy, 74, 132-157.

Mallik, S.U. (2012). Customer satisfaction, perceived service quality and mediating role of perceived value. International Journal of Marketing Studies, 68-72.

Martin Fasssracht, T.S. (2015). Determinants of choice satisfaction in a high involvement product choice. Journal of Management and Marketing Research.

Merrie, Brucks., \& P.H. (1990). The effect of bargaining attribute and attribute range knowledge on customer choice processes. Journal of consumer Research.409-419.

Mittal, V., \& Kamakura. W.A. (2001). Satisfaction, repurchase intent, and repurchase behaviour: Investigating the moderating effect of customer characteristics. Journal of marketing research. 3(1). 131-142.

Monroe, K. B. (2003). Pricing: Making profitable decisions. International editions. $3^{\text {rd }} \mathrm{ed}$. McGraw-Hill Education (Asia).

Mrs. Sharma, S., \& Sharma, A. (2018). Establishment of brand identity: A case study on Patanjali in India. International Research Journal of Engineering and Technology, 26022604.

Oliver, R. (1997). Satisfaction: A Behavioral Perspective on the Consumer. Boston: McGraw-Hill.

Parasuraman, A., Zeithaml, V. A., \& Berry, L. L. (1985). A conceptual model of service quality and its implications for future research, Journal of Marketing, 49, 41- 50.

Parasuraman, A., Zeithaml, V. A., \& Berry, L. L. (1988). SERVQUAL: A multiple item scale for measuring consumer perceptions of service quality, Journal of Retailing, 64 (1), p. $12-40.50$

Peter, J.P., \& Olsen, J.C. (1994). Understanding consumer Behavior. Third Edition. Boston: Irwin.

Pandey, P., \& Sah, R. (2016). Growth of Swadehi: A case study on Patanjali Ayurved Limited. International Journal of 
Engineering Technology Management and Applied Science, 7-14.

Rao, A. R. \& Monroe, K. B. (1989). The effect of price, brand name, and store name on buyers' perceptions of product quality: An integrative review. Journal of Marketing Research. 26. 351.

Regmi, Y. K. (2016). Consumer responce and their level of satisfaction towards Nepalese coffee. IJASBT, Vol 4(2): 213216.

Rekha, M., \& Gokila, K. (2015). A study on consumer awareness, attitude and preference towards herbal cosmetic. International Journal of Interdisciplinary and Multidisciplinary Studies (IJIMS), 2(4), 96-100.

Reichheld, F. F. (1996). The Loyal Effect. Harvard Business School Press. Boston.

Shin. D., \& Elliott, K.M. (2001). Measuring customer overall satisfaction: A multi attributes assessment. Services marketing quality. 22(1). 3-19.

Stapel, J. (1972). "Fair" or "psychological" pricing. Journal of Marketing Research, 109-110.

Yadav, M.I. (2015). A study of conceptual perception of herbal product in Bhopal. International Journal of Management Studies, 69-80.

Yi, Y. (1990). A critical review of consumer satisfaction, in Zeithaml. Review of Marketing. American Marketing Association, Chicago, IL. 68-123 